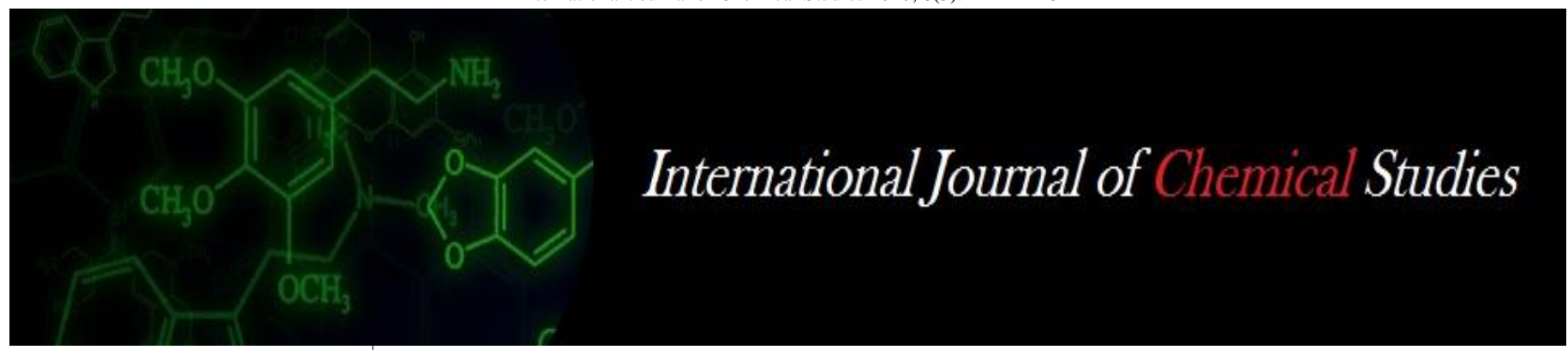

P-ISSN: 2349-8528

E-ISSN: 2321-4902

www.chemijournal.com

IJCS 2020; 8(3): 2444-2448

(C) 2020 IJCS

Received: 19-03-2020

Accepted: 21-04-2020

Nazim Hamid Mir

ICAR-Indian Grassland and

Fodder Research Institute,

Regional Research Station,

Srinagar, Jammu \& Kashmir, India

Suheel Ahmad

ICAR-Indian Grassland and

Fodder Research Institute,

Regional Research Station,

Srinagar, Jammu \& Kashmir, India

Sheeraz Saleem Bhat ICAR-Indian Grassland and Fodder Research Institute, Regional Research Station, Srinagar, Jammu \& Kashmir, India

Corresponding Author: Nazim Hamid Mir ICAR-Indian Grassland and Fodder Research Institute, Regional Research Station, Srinagar, Jammu \& Kashmir, India

\section{Forage yield of orchard grass (Dactylis glomerata L.) under different fertility levels on a karewa upland of Kashmir Himalaya}

\author{
Nazim Hamid Mir, Suheel Ahmad and Sheeraz Saleem Bhat
}

DOI: https://doi.org/10.22271/chemi.2020.v8.i3ai.9575

\begin{abstract}
The Union Territory of Jammu and Kashmir, with less than $4 \%$ of its cultivable area under fodder crops, produces green fodder that is $30-40 \%$ deficient than the demand. This shortage of fodder is the major cause of low productivity of the livestock in the hilly areas. Oat and berseem are the major fodder crops that are grown on about 25,000 hectares of land. Orchard grass or cocksfoot (Dactylis glomerata L.) is one of the important temperate perennial grasses with high productivity, forage quality, cold, drought and shade tolerance. Scanty information is available regarding the effect of nutrient management on forage productivity of orchard grass. Therefore, different fertility levels were evaluated to see the effect on different growth parameters and yield of Dactylis glomerata L. The study consisted of eight treatments: $\mathrm{T}_{1}=\mathrm{NPK} @ 100,60,40 \mathrm{~kg} / \mathrm{ha}, \mathrm{T}_{2}=\mathrm{NPK} @ 80,45,30 \mathrm{~kg} / \mathrm{ha}, \mathrm{T}_{3}=\mathrm{NPK} @ 60,30,20 \mathrm{~kg} / \mathrm{ha}, \mathrm{T}_{4}=\mathrm{NPK} @$ $75 \%$ of $\mathrm{T}_{1}+25 \%$ organic, $\mathrm{T}_{5}=\mathrm{NPK} @ 75 \%$ of $\mathrm{T}_{2}+25 \%$ organic, $\mathrm{T}_{6}=\mathrm{NPK} @ 75 \%$ of $\mathrm{T} 3+25 \%$ organic, $\mathrm{T}_{7}=\mathrm{FYM} @ 20 \mathrm{t} / \mathrm{ha}$ and $\mathrm{T}_{8}=$ control (No fertilizer). Highest plant height $(119.67 \mathrm{~cm})$, number of tillers $(484.33 / \mathrm{m}$ row $)$, leaf-stem ratio $(0.81)$, green fodder yield $(21.43 \mathrm{t} / \mathrm{ha})$ and dry fodder yield $(7.97 \mathrm{t} / \mathrm{ha})$ were recorded in the treatment $\mathrm{T}_{1}$ (NPK @ 100,60,40 kg/ha) followed by $\mathrm{T}_{2}$ and $\mathrm{T}_{4}$. Higher plant height, tiller number, leaf-stem ratio and consequently green and fodder yield in $T_{1}, T_{2}$ and $T_{4}$ may be attributed to positive effect of fertilization particularly nitrogen and higher responsiveness of orchard grass to fertilization.
\end{abstract}

Keywords: Dactylis glomerata L., forage yield, fertilizer, livestock, Himalaya

\section{Introduction}

Livestock rearing is an important livelihood activity of most farmers in North Western Himalayan region. Feed and fodder is the most important factor for animal production as it alone accounts for about $50 \%$ of total animal production. In animal husbandry about $65-75 \%$ expenditure is incurred in feeds and fodder. Though livestock production is more efficient from cultivated fodder, fodder cultivation is restricted to only about one per cent of the cultivated area in the entire Himalayan region. This is basically because of the preponderance of marginal and small land holdings in the area, climate and land topography. In Jammu and Kashmir, fodder cultivation has remained static and is less than 4\% of arable land (Mir et al., 2016) ${ }^{[1]}$. It produces around 64 lakh MT of green fodder and 35 lakh MT of dry fodder against a requirement of 139.13 lakh MT and 58.53 lakh MT of green and dry fodder, respectively (Ahmad et al., 2017) ${ }^{[2]}$. In other words, there is acute shortage of fodder especially green nutritious fodder, which is the major cause of low productivity of the livestock in the hilly areas. Therefore, increased production of fodder is essential to meet the nutritional requirements of the livestock. Livestock population, presently estimated at 7.8 million, is set to increase substantially, putting tremendous pressure on grazing lands and alpine pastures as well. Oat is the only major crop grown and now nearly 25,000 hectares of land is under oat cultivation, mainly for fodder purposes (Joshi, 2015) ${ }^{[3]}$. Due to harsh winter, crop seasonality, less than adequate production and quality and cultivation of other first choice crops, alternative options for cultivated fodder are to be explored. Temperate high yielding perennial grasses and legumes provide viable options for enhancing fodder resource base. These crops are perennial, hardy in nature, can grow on diverse land forms and with minimum inputs and provide large quantities of high quality fodder. Even pasture lands can be reseeded with perennial grasses and legumes to restore their productivity. Orchard grass or cocksfoot (Dactylis glomerata L.) 
is one such crop which offers many advantages owing to its perennial nature, high productivity, cold, drought and shade tolerance. Due to its high forage quality, i.e. sugar and protein contents, shade tolerance and persistence; Dactylis glomerata L. is used for hay or silage production and grazing worldwide (Last, et al., 2013) [4]. The main advantage of cocksfoot is greater forage production during summer compared to other forage grasses; it stays green after most prairie grasses have dried (USDA, 2010) ${ }^{[5]}$. As it is known to tolerate shade up to $80 \%$ without any reduction in the yield it is most suitable for cultivation in hortipasture and silvopasture systems. The crude protein content is also better than many oat varieties and varies from $28.3 \%$ at pre-joint to $12.5 \%$ at the late bloom stages (Hall, 2008) ${ }^{[6]}$. However, legume component may be included with the grass in the orchards as it is well- adapted to mixtures with legumes. As a cool-season perennial, cocksfoot may be harvested four times a year and remains productive during 6 to 10 years. As a dense, deep rooted perennial grass, it gives an excellent ground cover and may be used in rehabilitation programmes: for example soil erosion control and also acts as a good cover crop and prevents weed growth in orchards leading to better floor management.

Plant nutrition is essential for realizing potential yield of cultivated crop species. Orchard grass responds very well to good fertility management. It is one of the most responsive pasture grasses to nitrogen applications (Bush et al., 2012) ${ }^{[7]}$. Orchard grass can use high rates of nitrogen $(\mathrm{N})$ when grown on deep soils with adequate water supplies, making it valuable in nutrient recycling systems. Once established, it may be cultivated without additional fertilizer and without pesticides (Santen, 1996) ${ }^{[8]}$. However, it is preferred by livestock when grown with adequate plant nutrients (Voisin, 1988) ${ }^{[9]}$. Standardization of nutrient requirements of orchard grass is important for enhancing forage yield and its further recommendation for widespread, scientific and remunerative cultivation. Most of the studies worldwide show variable results. Scanty information is available regarding the effect of nutrient management on forage productivity of orchard grass. Therefore, under the current study different fertility levels were evaluated to see the effect on different growth parameters and yield of Dactylis glomerata L. in order to standardize, validate and recommend the most suitable fertilizer dosage for enhancing forage yield of Dactylis glomerata L.

\section{Materials and Methods}

The experiment consisted of eight treatments viz. T1= NPK @ 100, 60, 40 kg/ha, T2=NPK @ 80, 45, 30 kg/ha, T3=NPK @ 60,30, 20 kg/ha, T4=NPK @ 75\% 0f T1+25\% organic, T5=NPK @ 75\% of T2+25\% organic, T6=NPK @ 75\% of T3+ 25\% organic, T7=FYM @ 20 t/ha and T8= control (No fertilizer). A uniform seed rate of $12 \mathrm{~kg} / \mathrm{ha}$ with a row spacing of $30 \mathrm{~cm}$ was used in each treatment. In case of treatments with FYM (organic fertilizers), well rotten FYM was applied at the time of sowing in the first year and in February (early spring) in the second year. The experiment was carried out in RBD with three replications and a plot size of $8 \mathrm{~m} \times 5 \mathrm{~m}$. Half of $\mathrm{N}$ and full $\mathrm{P}$ and $\mathrm{K}$ were applied at sowing in the first year. Remaining $\mathrm{N}$ was applied during early (May) and late summer (August) in two equal splits in the first year. In the second year, half of $\mathrm{N}$ and full $\mathrm{P}$ and $\mathrm{K}$ was applied during early March (early spring) and remaining $\mathrm{N}$ was applied in two equal splits after each cut. The soil of experimental field was silt-clay loam in texture, neutral in reaction $(\mathrm{pH} ; 7.2)$ with medium organic carbon $(0.65 \%)$, available nitrogen $(290$ $\mathrm{kg} / \mathrm{ha}$ ), available phosphorus (14.2 $\mathrm{kg} / \mathrm{ha})$ and potassium (397 $\mathrm{kg} / \mathrm{ha})$. Electrical conductivity of the soil $(0.34 \mathrm{~d} / \mathrm{Sm})$ was normal. Average annual rainfall of the site was around 650 $\mathrm{mm}$. Data on various growth parameters and yield was recorded in the second year of experimentation (2019). Plant height of five plants per plot was recorded at harvesting and then averaged. Number of tillers in each treatment was counted in one metre of a row in the sampling area. The leafstem ratio was recorded after taking dry weights of leaves and stems (average of five plants). Harvesting was done in last week of May for the first cut and in first week of September for the second cut. Dry fodder yield was taken after oven drying green fodder (at $60{ }^{0} \mathrm{C}$ for 48 hours) taken from $1 \mathrm{~m}^{2}$ area and reported in $\mathrm{t} / \mathrm{ha}$.

\section{Results and Discussion \\ 1. Plant height}

The experimental results showed significant differences among different treatments for plant height (Table 1). Highest plant height of $119.67 \mathrm{~cm}$ was recorded in the treatment T1 (NPK@100,60,40 kg/ha) significantly higher than T6, T7 and T8. T4 (NPK @ 75\% Of T1+25\% organic) produced almost similar plants to T1 and T2. Higher plant height at higher fertilizer rates could be due to high availability of nutrients particularly nitrogen and high responsiveness of orchard grass to fertilization. The developmental morphology of these perennial grasses affects forage yield and quality and, hence, management decisions (Moore et al., 1991) ${ }^{[10]}$. Orchard grass plants are $50-120 \mathrm{~cm}$ tall (Bush et al., 2012) ${ }^{[7]}$. However average plant height recorded by Mut et al., 2008 [11], varied from $81.78 \mathrm{~cm}$ to $71.72 \mathrm{~cm}$ and were significant across different locations. Various growth parameter, like plant height and number of leaves per plant, in fodder maize, responded significantly to fertilization and the highest plant height was recorded at $125 \%$ of RDF. Since, nitrogen is an integral part of chlorophyll; it helped in more photosynthesis and resulted in better growth (Kumar et al., 2016) ${ }^{[12]}$.

\section{Number of tillers}

Highest number of tillers per $m$ row length was recorded in T1 (484.33) which were statistically at par with all other treatments except T7 (406.33) and T8 (357.67). Perennial grass tiller populations can be quantified to compare growth and developmental morphology (Moore and Moser, 1995) ${ }^{[10]}$. In general, the use of nitrogen fertilizer accelerates the appearance and death of tillers (Paiva et al., 2012) ${ }^{[13]}$. The number of tillers per $\mathrm{m}^{2}$ showed that nitrogen levels, sowing methods and their interactive effect significantly increased number of tillers per $\mathrm{m}^{2}$ and nitrogen applied @ 150\% of RD produced more tillers than $125 \%$ RD in fodder oat (Nawaz, 2017) ${ }^{[14]}$.

\section{Leaf-stem ratio}

The highest value of leaf-stem ratio (0.81) was recorded in the treatment T1 which was significantly higher than T6 (0.71), T7 (0.71) and T8 (0.67). Increasing nitrogen rates are related to increased leaf area and reduced stem percentage and consequently leading to increased leaf-stem ratio. The differences in leaf-stem ratio increased as fertilizer rate increased with lowest (0.275) at 0\% RDF and highest (0.295) at $125 \%$ RDF in fodder maize, (Kumar et al., 2016) ${ }^{[12]}$.

\section{Fodder yield}

Highest green fodder yield of $21.43 \mathrm{t} / \mathrm{ha}$ was recorded in the treatment $\mathrm{T} 1$ followed by a yield of $21.20 \mathrm{t} / \mathrm{ha}$ in $\mathrm{T} 4$ (Table 
2). T8 (13.07) recorded significantly lower yield than treatments T1 to T6. Higher green fodder yield in these treatments may be attributed to higher yield parameters like plant height, number of tillers and leaf-stem ratio due to high fertilization and responsiveness of orchard grass to fertilization. Similar to green fodder yield, dry fodder yield was recorded highest in T1 (7.97 t/ha) followed by T4 (7.90 t/ha). Significantly lower dry fodder yield was recorded in T7 (5.53) and T8 (4.20) than T1. Like green fodder yield, dry fodder yield in these treatments was also higher because of increased plant height, number of tillers and leaf-stem ratio due to high fertilization and responsiveness of orchard grass to fertilization. Dry matter yield in cocksfoot were positively correlated with plant height, panicle number, panicle length and 1000 grains weight (Parsa et al., 2012) ${ }^{[15]}$.

Cocksfoot responds very well to good fertility management. It is one of the most responsive pasture grasses to nitrogen applications (Bush et al., 2012) ${ }^{[7]}$. Nitrogen at a rate of 50 to 75 pounds per acre (approximately 55 to $87 \mathrm{~kg} / \mathrm{ha}$ ) in early spring and after each cutting is generally recommended to as high as $170 \mathrm{~kg} / \mathrm{ha}$ (Hall, 2008) ${ }^{[6]}$. However, good produce can be obtained even with the low input like fertilizer and organic manure usage. It has been shown that $\mathrm{N}$ fertility status of pastures affects grazing preference (Edwards et al., 1993) [16]. In an experiment conducted at Palampur (HP) the mean green forage yield of $22.90 \mathrm{t} / \mathrm{ha}$, dry forage yield of $8.57 \mathrm{t} / \mathrm{ha}$ and crude protein content of $11.20 \%$ was recorded in orchard grass. An increase of $38.4 \%$ in green forage and $31.2 \%$ in dry forage yield was observed over local system i,e no introduction of improved species. A fertilizer dosage of $\mathrm{N}$, $\mathrm{P}_{2} \mathrm{O}_{5}$ and $\mathrm{K}_{2} \mathrm{O} @ 60,60$ and $30 \mathrm{~kg} / \mathrm{ha}$ was used in the study (Kumar, et al, 2015) ${ }^{[17]}$. The green fodder yield of $22.32 \mathrm{t} / \mathrm{ha}$ and dry fodder yield of $7.39 \mathrm{t} / \mathrm{ha}$ in cocksfoot was obtained in an apple based hortipastoral system under temperate conditions of Kashmir where a fertilization dosage of $\mathrm{N}, \mathrm{P}_{2} \mathrm{O}_{5}$ and $\mathrm{K}_{2} \mathrm{O} @ 30,60,30 \mathrm{~kg} / \mathrm{ha}$ was used in addition to the fertilizers and FYM added to the apple trees (Ahmad et al., 2018) ${ }^{[18]}$. The average dry matter yield of both native and exotic grasses varies considerably from 2.5 t/ha in Agrostis spp. to 10.0 t/ha in Dactylis glomerata in Kashmir Himalaya (Dar et al., 2007) ${ }^{[19]}$. However, it was found that N @ 240-
$360 \mathrm{~kg} / \mathrm{ha}$ fertilized cocksfoot could be harvested four times per vegetation season. Hay yields may be up to $13.5 \mathrm{t} / \mathrm{ha}$ with adequate fertilizer and up to 5-6 t/ha with no additional fertilizer. The fertilization with higher nitrogen rate had a positive effect on cocksfoot biomass yield of swards, which were harvested for the first time at heading stage (Santen et $a l ., 1996)^{[8]}$. In Canterbury, reported cocksfoot annual yields range from $7.5 \mathrm{t} \mathrm{DM} /$ ha to $28.6 \mathrm{t} \mathrm{DM} / \mathrm{ha}$. The lower yield (Stevens et al., 1992) ${ }^{[20]}$ indicates an average year with no $\mathrm{N}$ and dry land conditions whereas the high yield (Peri et al., 2002a) [21] was produced under non-limiting water and $\mathrm{N}$ conditions. Dry land cocksfoot pastures supplied with adequate $\mathrm{N}$ produced $80 \%$ more yield annually than pastures supplied with irrigation alone (Peri et al., 2002b) ${ }^{[22]}$. In the three investigated years of evaluating Alfalfa-Dactylis mixtures, fertilization significantly increased the yield, but the differences between the quantities of 70 and $140 \mathrm{~kg} \mathrm{~N} \mathrm{ha}^{-}$ ${ }^{1}$ were not significant so that the increased investment in higher amounts of nitrogen fertilization were not economically justified (Bijelic et al., 2013) ${ }^{[23]}$. Vassilev (2004) ${ }^{[24]}$ presented in his research that alfalfa mixtures with cocksfoot achieved higher dry matter yield of 15.6-16.8 $\mathrm{t} \mathrm{ha}^{-1}$ compared to mixtures with tall fescue 15.1-15.6 $\mathrm{t} \mathrm{ha}{ }^{-1}$. Dactylis glomerata, fertilized as nitrogen @ $150 \mathrm{~kg} / \mathrm{ha}$ applied in spring N@60, and N@45 kg after the first and second cut, phosphorus and potassium fertilizers as P @ 60 and K @ $90 \mathrm{~kg} / \mathrm{ha}$ recorded an annual dry matter yield of around 14 $\mathrm{t} / \mathrm{ha}$ in the first and $12 \mathrm{t} / \mathrm{ha}$ in the second year and $3.49 \mathrm{t} / \mathrm{ha}$ aftermath dry matter yield during the drought conditions (Lemeziene et al., 2004) ${ }^{[25]}$. A good dry matter yield of Dactylis aftermath in the first and second years of herbage utilization can be explained by an excellent regrowth of this grass species after cuts and a good drought resistance. The yield stability of Dactylis glomerata grown at limited water supply conditions has been mentioned in the literature (Waldron et al. 2002) ${ }^{[26]}$.

\section{Acknowledgements}

The authors thank Indian Council of Agricultural Research for financial help during the course of investigation.

Table 1: Effect of different treatments on plant height, number of tillers and leaf-stem ratio

\begin{tabular}{|c|c|c|c|}
\hline Treatment & Plant height $(\mathbf{c m})$ & Number of tillers (per m row length) & Leaf-stem ratio \\
\hline T1= NPK @ 100, 60, 40 kg/ha & 119.67 & 484.33 & 0.81 \\
\hline T2= NPK @ 80, 45, 30 kg/ha & 116.33 & 478.33 & 0.77 \\
\hline T3= NPK @ 60, 30, 20 kg/ha & 114.67 & 464.33 & 0.79 \\
\hline T4= NPK @ 75\% 0f T1+ 25\% organic & 118.67 & 479.00 & 0.79 \\
\hline T5= NPK @ 75\% 0f T2+ 25\% organic & 115.33 & 464.33 & 0.75 \\
\hline T6= NPK @ 75\% 0f T3+ 25\% organic & 111.33 & 453.00 & 0.71 \\
\hline T7=FYM @ 20 t/ha & 103.00 & 406.33 & 0.71 \\
\hline T8= Control (No fertilizer) & 97.67 & 357.67 & 0.67 \\
\hline C.D & 5.99 & 70.82 & 0.08 \\
\hline
\end{tabular}

Table 2: Effect of different treatments on green and dry fodder yield

\begin{tabular}{|c|c|c|}
\hline Treatment & Green fodder yield (t/ha) & Dry fodder yield (t/ha) \\
\hline T1= NPK @ 100, 60, 40 kg/ha & 21.43 & 7.97 \\
\hline T2= NPK @ 80, 45, 30 kg/ha & 20.77 & 7.27 \\
\hline T3= NPK @ 60, 30, 20 kg/ha & 18.83 & 6.93 \\
\hline T4= NPK @ 75\% 0f T1+ 25\% organic & 21.20 & 7.90 \\
\hline T5= NPK @ 75\% 0f T2+ 25\% organic & 20.07 & 7.13 \\
\hline T6= NPK @ 75\% 0f T3+ 25\% organic & 18.67 & 6.73 \\
\hline T7=FYM @ 20 t/ha & 16.00 & 5.53 \\
\hline T8= Control (No fertilizer) & 13.07 & 4.20 \\
\hline C.D & 3.02 & 2.04 \\
\hline
\end{tabular}



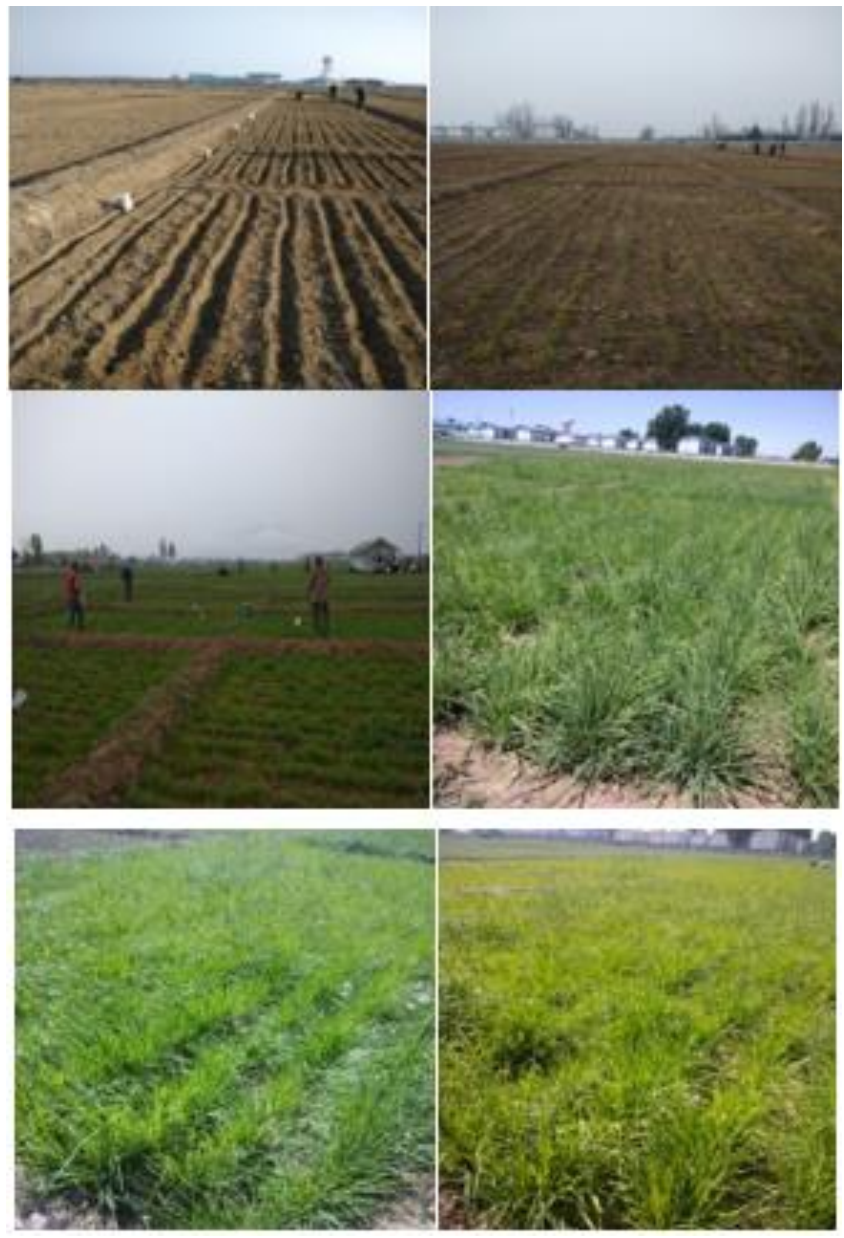

Photographs showing different stages of experimentation

\section{References}

1. Mir NH, Ahmad S, Verma DK. Livestock rearingsectorial status and fodder-feed strategies in Kashmir Himalayas. Annals of Biology. 2016; 32(2):253-259.

2. Ahmad S, Khan PA, Verma DK, Mir N, Singh JP, Dev I, Roshetko J. Scope and potential of hortipastoral systems for enhancing livestock productivity in Jammu and Kashmir. Indian Journal of Agroforestry. 2017; 19(1):4856.

3. Joshi M. Oat (Avena sativa L.), Textbook of field crops. 2018, 285.

4. Last L, Widmer F, Fjellstad W, Stoyanova S, Kolliker R. Genetic diversity of natural orchardgrass (Dactylis glomerata L.) populations in three regions in Europe. BMC Genetics. 2013; 14:1-13.

5. USDA. GRIN- Germplasm Resources Information Network. National Germplasm Resources Laboratory, Beltsville, Maryland, 2010.

6. Hall HM. Agronomy facts 25, Orchard grass. Penn State Extension (extension. psu. education), 2008.

7. Bush T, Ogle D, John L, Stannard M, Jensen K. Ed. St. John. Plant Guide for Orchard grass (Dactylis glomerata). 2012; USDA-Natural Resources Conservation Service, Aberdeen Plant Materials Center. Aberdeen, Idaho 83210.

8. Santen EV, Sleper DA. Orchardgrass. In: Moser I.E., Buxton D.R., Casler M.D. (eds.): Cool-season forage grasses. Agron. Monogr. 34, Am. Soc. Agron., Madison, Wisconsin: 1996, 503-534.

9. Voisin A. Grass productivity. Island Press, USA. 1988; 384.
10. Moore KJ, Moser LE. Quantifying developmental morphology of perennial grasses. Crop Sci. 1995; 35:3743.

11. Mut H, Ayan I. Determination of Some Morphological and Agricultural Characters of Natural Orchardgrass Plants (Dactylis glomerata ssp. glomerata L.) Collected from Different Places of Ondokuz Mayis University Campus Area, Turkey. Asian Journal of Chemistry. 2008; 20(3):2405-2413

12. Kumar R, Singh M, Tomar SK, Meena B. Productivity and nutritive parameters of fodder maize under varying plant density and fertility levels for improved animal productivity. Indian Journal of Animal Research. 2016; 50(2):199-202

13. Paiva AJ, Silva SC, Pereira LET, Guarda VDA, Pereira PM, Caminha FO. Structural characteristics of tiller age categories of continuously stocked marandu palisade grass swards fertilized with nitrogen. R. Bras. Zootec., 2012; 41(1):24-29

14. Nawaz MQ. Effect of different sowing methods and nitrogen levels on fodder yield of oat in salt affected soil. Pakistan Journal of Agricultural Research. 2017; 30(4):323-328.

15. Parsa MS, Jafari AA, Assadian G. Seed yield variation and its relation with phenotypic characteristics in populations of cocksfoot (Dactylis glomerata) grown in Hamadan, Iran. Annals of Biological Research. 2012; 3(12):5577-5582

16. Edwards GR, Lucas RJ, Johnston MR. Grazing preference for pasture species by sheep is affected by endophyte and nitrogen fertility. Proceedings of the New Zealand Grassland Association. 1993; 55:137-141.

17. Kumar N, Sood BR, Kumar S. Performance of improved forage species under dry temperate conditions of North Western Himalayas. Paper presented in XXIII International Grassland Congress, November 20-24, New Delhi, India, 2015.

18. Ahmad S, Khan PA, Mughal AH, Qaiser KN, Zaffar SN, Mir NH et al. Evaluation of apple based hortipastoral systems in Kashmir Himalaya. Multilogic in Science. 2018; 25(3):308-310.

19. Dar NA, Khan HU, Ganai NA, Burman K. Evaluation studies on the dry matter production and quality of annual and perennial grasses. Forage and Grazing lands. 2007, 5.

20. Stevens DR, Baxter GS, Stewart A, Casey MJ, Miller KB. Grasslands Kara cocksfoot: A productive cultivar under lax grazing. Proceedings of the New Zealand Grassland Association. 1992; 54:143-146.

21. Peri PL, Moot DJ, Lucas RJ. Urine patches indicate yield potential of cocksfoot. Proceedings of the New Zealand Grassland Association. 2002; 64:73-80

22. Peri PL, Moot DJ, McNeil DL, Varella AC, Lucas RJ. Modelling net photosynthetic rate of field-grown cocksfoot leaves under different nitrogen, water and temperature regimes. Grass and Forage Science. 2002; 57:61-71.

23. Bijelic Z, Tomic Z, Ruzic-Muslic D, Mandic V, Simic A, Vuckovic S. Yield potential and quality of forage Mixtures of alfalfa with cocksfoot and Tall fescue depending on the nitrogen Fertilization. Biotechnology in Animal Husbandry. 2013; 29(4):695-704

24. Vassilev E. Forage productivity of some Bulgarian lucerne in mixtures with grasses. Proceeding of the 20th European Grassland Federation, Land use systems in 
Grassland Dominated Regions. Grassland Science in Europe. 2004; 9:401- 403.

25. Lemeziene N, Kanapeckas J, Tarakanovas P, Nekrosas S. Analysis of dry matter yield structure of forage grasses. Plant Soil Environ. 2004; (6):277-282

26. Waldron BL, Asay KH, Jensen KB. Stability and yield of cool-season pasture grass species grown at five irrigation levels. Crop Sci. 2002; 42:890-896. 